\title{
Role of Norepinephrine in IL-1 $\beta$-Induced Chondrocyte Dedifferentiation under Physioxia
}

\author{
Saskia Speichert, Natalie Molotkov, Karima El Bagdadi, Andrea Meurer, Frank Zaucke \\ and Zsuzsa Jenei-Lanzl *
}

Dr. Rolf M. Schwiete Research Unit for Osteoarthritis, Orthopaedic University Hospital Friedrichsheim gGmbH, Marienburgstr. 2, 60528 Frankfurt/Main, Germany; saskia.speichert@web.de (S.S.); natalie.molotkov@friedrichsheim.de (N.M.); karima.elbagdadi@friedrichsheim.de (K.E.B.); andrea.meurer@friedrichsheim.de (A.M.); frank.zaucke@friedrichsheim.de (F.Z.)

* Correspondence: zsuzsa.jenei-lanzl@friedrichsheim.de; Tel.: +49-69-6705-408

Received: 13 December 2018; Accepted: 5 March 2019; Published: 11 March 2019

\begin{abstract}
As part of the pathogenesis of osteoarthritis (OA), chondrocytes lose their phenotype and become hypertrophic, or dedifferentiate, mainly driven by interleukin-1 $\beta$ (IL-1 $\beta$ ). The contribution of other factors to the dedifferentiation process is not completely understood. Recent studies suggested a dose-dependent role for the sympathetic neurotransmitter norepinephrine (NE) in OA chondrocyte metabolism. Therefore, the aim of this study was to analyze the contribution of $\mathrm{NE}\left(10^{-8} \mathrm{M}, 10^{-6} \mathrm{M}\right)$ to human articular OA chondrocyte dedifferentiation in the absence or presence of IL-1 $\beta(0.5 \mathrm{ng} / \mathrm{mL})$. Here, we demonstrate that $\mathrm{OA}$ chondrocytes express $\alpha 2 \mathrm{~A}-, \alpha 2 \mathrm{C}$ - and $\beta 2$-adrenoceptors (AR) and show the characteristic shift towards a fibroblast-like shape at day 7 in physioxic monolayer culture. NE alone did not affect morphology but, in combination with IL-1 $\beta$, markedly accelerated this shift. Moderate glycosaminoglycan (GAG) staining was observed in untreated and NE-treated cells, while IL-1 $\beta$ strongly decreased GAG deposition. IL-1 $\beta$ alone or in combination with NE decreased SOX9, type II collagen, COMP, and aggrecan, and induced MMP13 and ADAMTS4 gene expression, indicating an accelerated dedifferentiation. NE alone did not influence gene expression and did not modulate IL- $1 \beta$-mediated effects. In conclusion, these results indicate that low-grade inflammation exerts a dominant effect on chondrocyte dedifferentiation and should be targeted early in OA therapy.
\end{abstract}

Keywords: osteoarthritis; chondrocytes; dedifferentiation; norepinephrine; interleukin-1 $\beta$; adrenoceptors; physioxia

\section{Introduction}

Osteoarthritis (OA) is one of the most common painful and disabling chronic degenerative joint diseases worldwide [1,2]. Besides ageing and obesity, further OA risk factors have been identified during the past decades such as genetics, gender, diet, injury, or overloading of the joints [3]. However, there are still many deficits in our understanding of the exact pathophysiology of OA at the molecular level. During OA progression, the articular chondrocyte phenotype characterized by high type II collagen and proteoglycan expression becomes unstable due to hypertrophic terminal differentiation or dedifferentiation [4-6]. Hypertrophic chondrocytes start to produce type X collagen and the type II collagen-degrading enzyme MMP-13, whereas dedifferentiating chondrocytes display a fibroblast-like morphology with high type I collagen production and concomitant down-regulation of type II collagen, aggrecan, and cartilage oligomeric matrix protein (COMP) expression [7-9]. Articular cartilage-derived chondrocytes cultured in monolayer dedifferentiate rapidly and show the characteristic morphological shift towards a fibroblast-like shape, as well as changes in extracellular matrix (ECM) synthesis as described above [10]. Therefore, monolayer chondrocyte culture can be used as an in vitro model of 
chondrocyte dedifferentiation allowing analysis of the effect of different factors on the dedifferentiation process. Chondrocyte dedifferentiation in OA cartilage tissue is primarily induced by pro-inflammatory mediators such as IL-1 $\beta$, the main pro-inflammatory cytokine in OA [11,12]. IL-1 $\beta$ has been detected in synovial fluid of OA patients at concentrations of $1.25-100 \mathrm{pg} / \mathrm{mL}[13,14]$, representing a low level of inflammation compared to other chronic degenerative and inflammatory joint diseases like rheumatoid arthritis, in which IL-1 $\beta$ levels can reach up to $15 \mathrm{pg} / \mathrm{mL}$, accompanied by very high TNF- $\alpha$ concentrations [15]. However, other factors that might contribute, as well as underlying molecular mechanisms inducing chondrocyte dedifferentiation in OA, are still largely unknown. During the last few decades, the first evidence emerged that besides aging, genetics, trauma, and inflammation, endocrine and sympathetic nervous factors also influence cartilage homeostasis, regeneration capacity, and OA development [16]. Sympathetic nerve fibers are characterized by high tyrosine hydroxylase (TH) expression and activity [17]. This enzyme is responsible for the conversion of tyrosine to L-DOPA, the first rate-limiting step in the biosynthesis of catecholamines such as dopamine (DA), NE, and epinephrine (E). Recently, TH-positive cells and nerve fibers were detected in synovial tissue and increased levels of NE were found in the synovial fluid of knee trauma and OA patients, whereas DA and E were not detectable [18]. It is also known that OA articular chondrocytes express adrenoceptors (ARs), suggesting a role for the sympathetic nervous system in OA pathogenesis [19]. Recent studies demonstrated that NE can modulate IL-1 $\beta$-induced changes in chondrocyte metabolism mediated by different AR subtypes depending on the concentration of NE [19]. Due to the affinity of the distinct ARs, NE in low concentrations $\left(\leq 10^{-7} \mathrm{M}\right)$ primarily acts via $\alpha$ ARs, while $\beta$ ARs are preferentially activated at high NE concentrations $\left(\geq 10^{-7} \mathrm{M}\right)[20,21]$. However, these studies were performed under $20 \% \mathrm{O}_{2}$ concentration, representing a hyperoxic and unphysiological condition for articular chondrocytes, because $\mathrm{O}_{2}$ concentrations in cartilage tissue lie between 1-3\% (physioxia) [22]. Interestingly, it has been shown recently that physioxia alone leads to a deceleration of the dedifferentiation process. An upregulation of SOX9 and COL2A1 under physioxic conditions led to a prolonged stabilization of the chondrocytic phenotype [23].

Therefore, the aim of this study was to analyze for the first time the contribution of NE to the dedifferentiation response of human articular OA chondrocytes in the absence or presence of low-dose IL-1 $\beta$ under physioxic conditions. Based on the studies described above, we hypothesized that NE treatment accelerates chondrocyte dedifferentiation and might potentiate the effects of IL-1 $\beta$ on the dedifferentiation process. The results will provide new insight into OA pathophysiology and might unravel potential novel therapeutic options for OA treatment.

\section{Results}

\subsection{Chondrocyte Dedifferentiation under Physioxia}

First, morphological changes and alterations in the expression of ECM-related genes in OA chondrocytes after seven days in monolayer culture were investigated. One day after isolation, chondrocytes attached to the culture plate and exhibited a round and polygonal morphology (Figure 1A). After seven days in monolayer under physioxia, chondrocytes dedifferentiated and showed the characteristic shift towards a fibroblast-like shape (Figure 1A). Gene expression levels of COL1A1 and COL2A1 increased, while COL10A1, matrix metallopeptidase 13 (MMP13), and ADAM metallopeptidase with thrombospondin type 1 motif 4 (ADAMTS4) expression decreased during dedifferentiation, compared to chondrocytes at day 0 (COL1A1, $p<0.001$; COL2A1, $p=0.007$; COL10A1, $p=0.007$; MMP13, $p=0.008$; ADAMTS4, $p=0.014$ ). The mRNA expression of the transcription factor SOX9, as well as of the ECM components COMP and aggrecan (ACAN), remained stable until day 7 (Figure 1B). No age- or gender-dependent differences were observed regarding chondrocyte dedifferentiation under physioxia. 


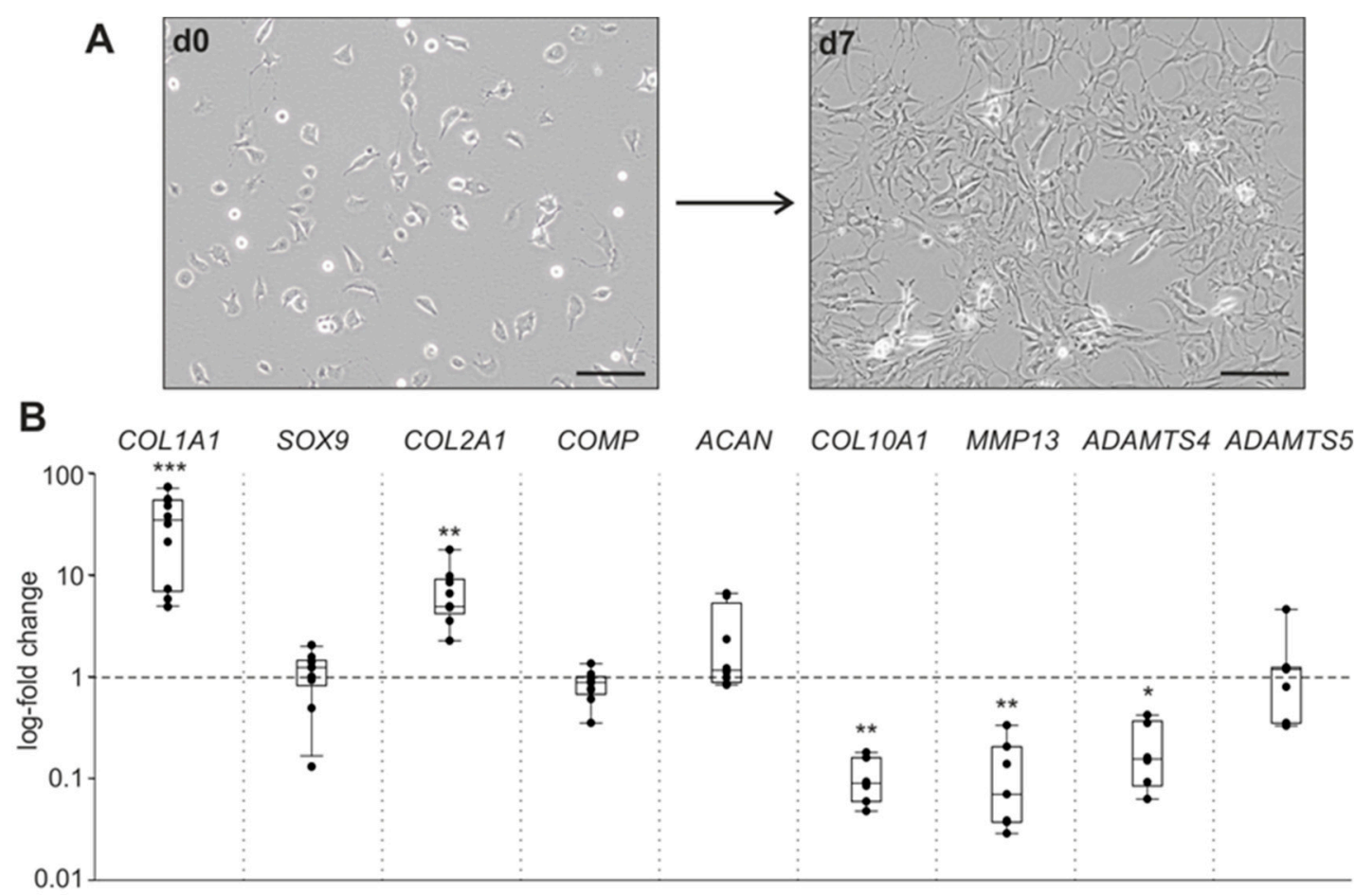

Figure 1. Chondrocyte phenotype shift during dedifferentiation under physioxia. (A) Change of human osteoarthritis (OA) chondrocytes from a polygonal to a fibroblast-like morphology after seven days under physioxic conditions (representative images of chondrocytes isolated from one OA patient, magnification $200 \times$, scale bars represent $100 \mu \mathrm{m}$ ). (B) Gene expression changes of the transcription factor SOX9, ECM components, and ECM-degrading enzymes after seven days in monolayer culture under physioxic conditions compared to day 0 (gene expression on day $0=1$, represented by the dashed line). All experiments were carried out with cells from 8-10 patients, using duplicates for each patient. Each circle shows the mean of the duplicates. Data are presented as box plots, where the boxes represent the 25 th to 75 th percentiles, the lines within the boxes represent the median, and the lines outside the boxes represent the 10th and 90th percentiles. Significant $p$-values against day 0 are presented as: ${ }^{*}(p \leq 0.05),{ }^{* *}(p \leq 0.01),{ }^{* * *}(p \leq 0.001)$.

\subsection{AR and IL-1ßR Expression Profile of Human Articular Chondrocytes}

Next, the expression profile of ARs and the IL-1 $\beta$ receptor (IL-1 $1 \beta R$ ) in OA chondrocytes was examined, because the presence of distinct receptors is the prerequisite for NE or IL-1 $\beta R$ action. Freshly isolated OA chondrocytes expressed distinct $\alpha$ - and $\beta$-AR subtypes (Figure 2) as well as the IL-1 $\beta R$ (Supplementary Figure S2). Gene expression levels of $\beta 2$-AR and IL-1 $\beta R$ were the highest, $\alpha 1 \mathrm{~A}-\mathrm{AR}$ was moderately expressed, and $\alpha 2 \mathrm{~A}$-AR gene expression was only weakly detectable on day 0 . The receptors $\alpha 1 \mathrm{~A}_{-}, \alpha 2 \mathrm{~A}-, \alpha 2 \mathrm{~B}-, \alpha 2 \mathrm{C}_{-}$, and $\beta 1-\mathrm{AR}$ were not detected, and nor was the TH gene (Figure 2). No age- or gender-dependent differences were observed regarding AR or IL-1 $\beta R$ expression in chondrocytes.

\subsection{NE-Induced Intracellular Signaling in Human Articular Chondrocytes}

Chondrocytes were treated for 15 min with NE $\left(10^{-8}\right.$ or $\left.10^{-6} \mathrm{M}\right)$ and the activation of the two major AR-mediated signaling pathways, the ERK1/2 and PKA pathways, were analyzed. Both low and high NE concentrations induced ERK1/2 phosphorylation after $15 \mathrm{~min}$, while PKA phosphorylation was not increased by any treatment (Figure 3). 


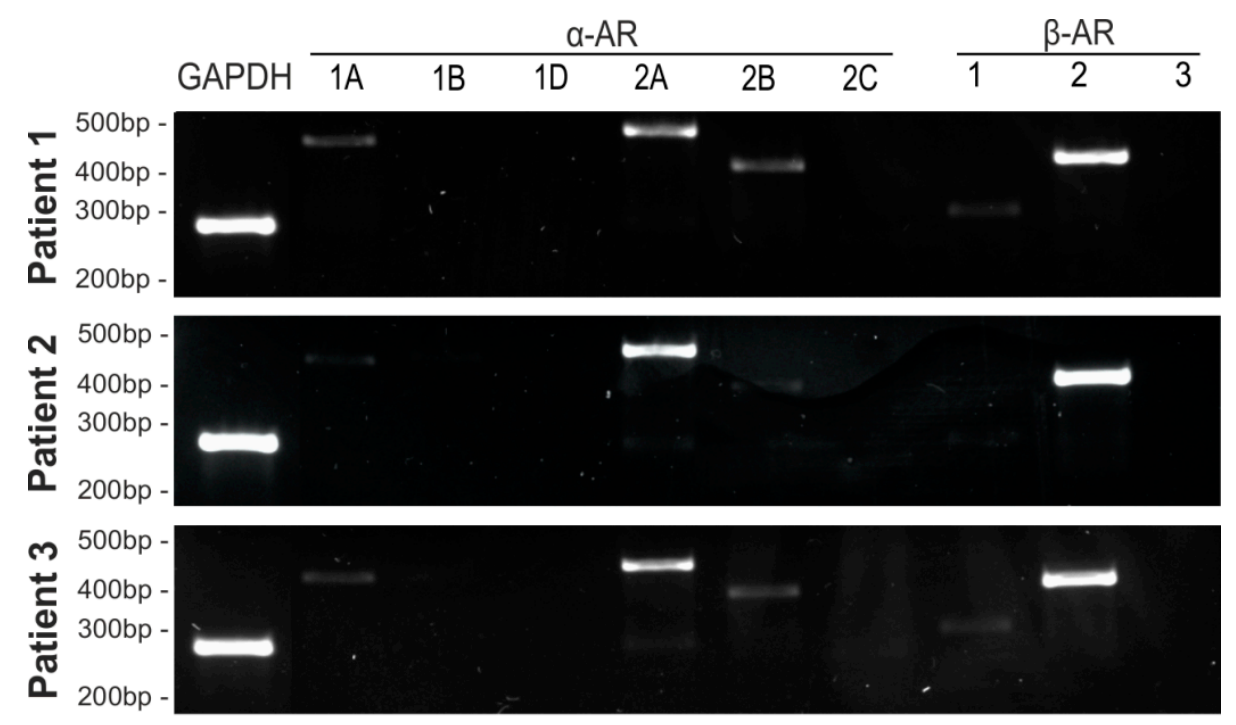

Figure 2. Adrenergic receptor profile of OA chondrocytes. Gene expression of different adrenoceptor subtypes in untreated primary chondrocytes isolated from three patients at day 0 (representative images of three OA donor cell isolations).

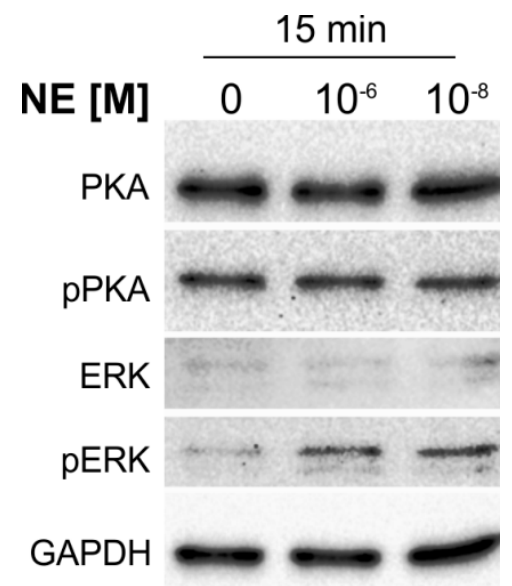

Figure 3. NE-mediated activation of intracellular signaling pathways in chondrocytes. No changes in PKA phosphorylation are visible, while both low and high NE concentrations increase phosphorylation of ERK after $15 \mathrm{~min}$ (representative images of cells isolated form one OA patient).

\subsection{Effects of NE and IL-1 $\beta$ on Chondrocyte Morphology and Viability during Dedifferentiation}

After seven days in culture, untreated chondrocytes showed the characteristic morphological changes towards a fibroblastoid shape, as detected by phase contrast microscopy and actin cytoskeleton staining (Figure $4 \mathrm{~A}, \mathrm{~B})$. Chondrocytes treated with NE alone $\left(10^{-6} \mathrm{M}\right.$ and $\left.10^{-8} \mathrm{M}\right)$ did not differ morphologically from controls (Figure $4 \mathrm{~A}, \mathrm{~B}$ ). IL-1 $\beta$ treatment resulted in an accelerated morphological shift with more elongated cells (Figure 4A) and clearly visible phalloidin-stained stress fibers (Figure 4B), as described earlier [10,24]. Similarly, chondrocytes incubated with a combination of IL-1 $\beta$ and NE showed a morphology comparable to the IL-1 $\beta$-treated group, with pronounced elongation of the cell shape (Figure 4A) and strong staining of actin stress fibers (Figure $4 \mathrm{~B}$ ). The age or the gender of patients did not influence the NE- and IL- $1 \beta$-mediated changes in chondrocyte morphology and viability during dedifferentiation.

Compared to untreated control, neither NE or IL-1 $\beta$ treatment, nor combined NE and IL-1 $\beta$ treatment, changed cell viability of chondrocytes (Supplementary Figure S1). 
A
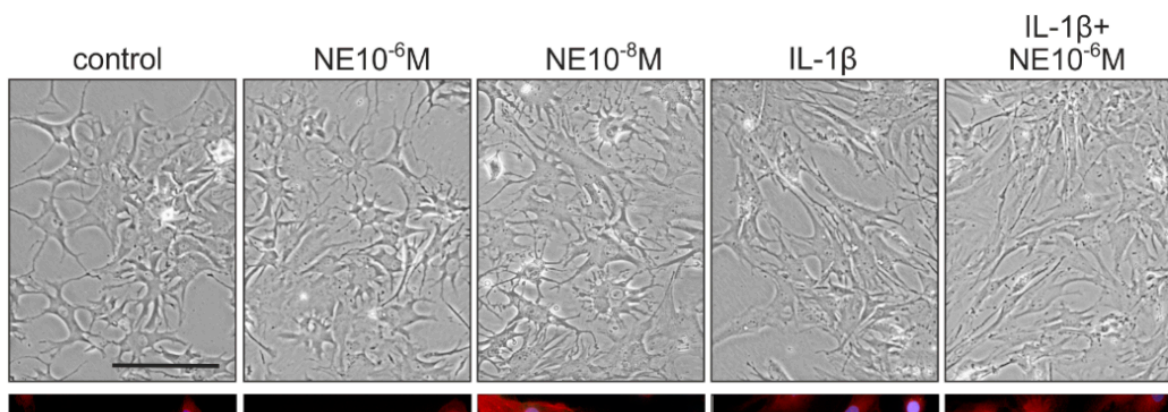

IL-1 $1 \beta+$

B
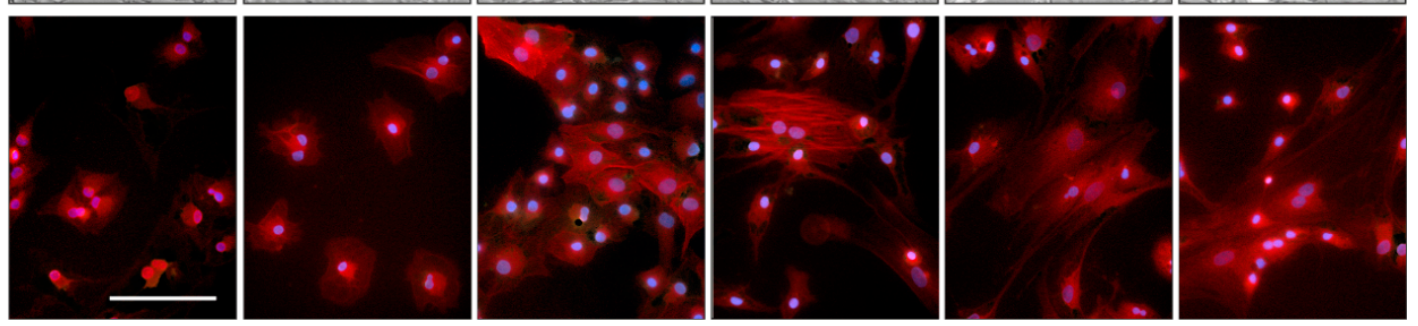

Figure 4. Effects of NE and IL-1 $\beta$ on chondrocyte morphology and cytoskeleton organization. (A) Phase contrast microscopic appearance of OA chondrocytes at day 7 after treatment with NE, IL-1 $\beta$, or NE + IL-1 $\beta$ (representative images of cells isolated form one OA patient, magnification $200 \times$ ). (B) Phalloidin staining of the actin cytoskeleton at day 7 after treatment with NE, IL-1 $\beta$, or NE + IL-1 $\beta$ (representative images of cells isolated form one OA patient, magnification $200 \times$, red: actin, blue: nuclei). Scale bars represent $100 \mu \mathrm{m}$.

\subsection{NE- and IL-1 $\beta$-Mediated Effects on Gene Expression}

Compared to the untreated control with significantly $(p<0.001)$ elevated COL1A1 gene expression after seven days, no changes in COL1A1 expression were detected in chondrocytes incubated with low or high NE concentrations, with IL-1 $\beta$ alone, or with NE and IL-1 $\beta$ (Figure 5). SOX9 expression was not influenced by NE treatment compared to untreated control group at day 7 , while IL-1 $\beta$ alone or in combination with NE slightly decreased the SOX9 level. Similarly, COL2A1 was not affected by NE treatment compared to day 7 control, but IL-1 $\beta$ alone or in combination with NE caused a strong and significant $(p=0.006)$ decrease of COL2A1. No changes in COMP gene expression of chondrocytes were detectable after incubation with NE, however, treatment with IL-1 $\beta$ alone or in combination with NE resulted in significantly $(p=0.006)$ reduced COMP levels $(p<0.001$ to day 0$)$. Compared to untreated control, ACAN expression was not influenced by NE, but IL-1 $\beta$ alone or in combination with $10^{-6} \mathrm{M}$ NE reduced ACAN gene expression (IL- $1 \beta$ to control $p=0.039$, IL- $1 \beta+10^{-6} \mathrm{M}$ NE to control $p$ $=0.015)$. Neither NE or IL-1 $\beta$ alone, nor the simultaneous treatment with NE and IL-1 $\beta$, caused any effect on the reduced COL10A1 gene expression of untreated control chondrocytes after seven days. The decreased MMP13 level of untreated chondrocytes at day 7 was not affected by NE treatment, while IL-1 $\beta$ alone or in combination with NE significantly (IL- $1 \beta$ to control $p=0.006$, IL- $1 \beta+10^{-6} \mathrm{M}$ $\mathrm{NE}$ to control $p=0.002$, IL-1 $\beta+10^{-8} \mathrm{M}$ NE to control $\left.p=0.007\right)$ induced MMP13 gene expression. Gene expression of the aggrecanase ADAMTS4 did not change after NE treatment compared to untreated control group at day 7 , but increased when chondrocytes were incubated with IL-1 $\beta$ alone or with IL-1 $\beta$ in combination with NE (IL-1 $\beta$ to control $p=0.026$, IL- $1 \beta+10^{-6} \mathrm{M}$ NE to control $p=0.026$, IL-1 $\beta+10^{-8} \mathrm{M}$ NE to control $\left.p=0.041\right)$. In contrast, ADAMTS5 gene expression remained unchanged; neither NE or IL- $1 \beta$ alone, nor the simultaneous treatment with NE and IL-1 $\beta$, caused any effect on ADAMTS5 gene expression (Figure 5). The age or the gender of patients did not influence the NE- and IL-1 $\beta$-mediated changes in chondrocyte gene expression during dedifferentiation. 

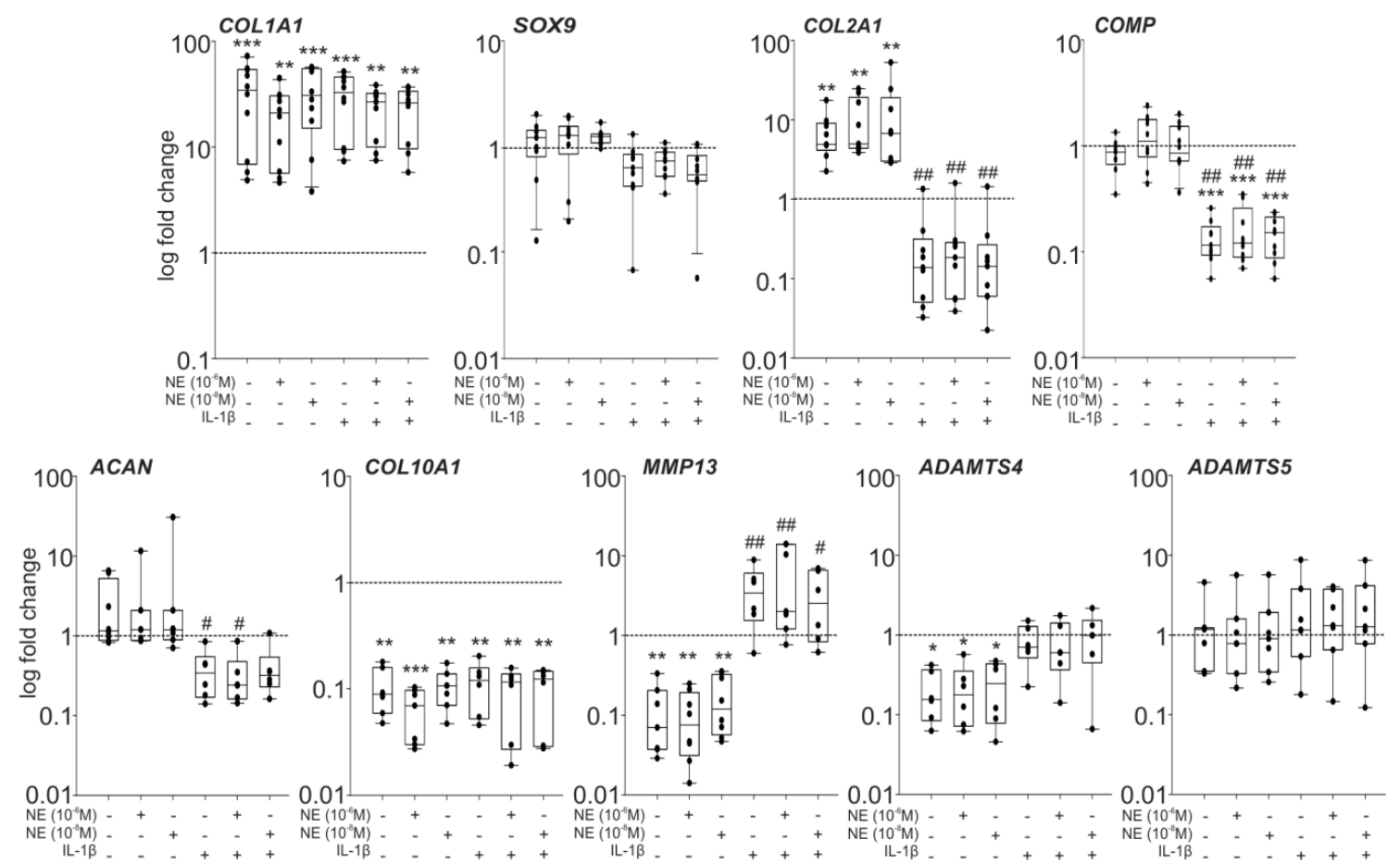

Figure 5. Effects of NE and IL-1 $\beta$ on OA chondrocyte gene expression. Gene expression changes of the transcription factor SOX9, ECM components, and ECM-degrading enzymes after seven days in monolayer culture under NE and/or IL-1 $\beta$ influence and physioxic conditions compared to day 0 (gene expression on day $0=1$, represented by the dashed line). All experiments were carried out with cells from 8-10 patients, using duplicates for each patient. Each circle shows the mean of duplicates per patient. Box plots are explained in legend to Figure 1. Significant $p$-values against day 0 are presented as: ${ }^{*}(p \leq 0.05),{ }^{* *}(p \leq 0.01),{ }^{* * *}(p \leq 0.001)$. Significant $p$-values against untreated control are presented as: ${ }^{\#}(p \leq 0.05),{ }^{\# \#}(p \leq 0.01)$.

\subsection{NE- and IL-1ß-Mediated Effects on ECM Deposition}

DMMB (1,9-dimethyl-methylene blue) staining of sulphated glycosaminoglycans (sGAGs) after seven days in monolayer culture showed a clearly visible GAG deposition in the untreated control group (Figure 6). Treatment of chondrocytes with low or high NE concentration did not result in any differences regarding GAG deposition (Figure 6). In contrast, chondrocytes treated with IL-1 $\beta$ alone, or with IL-1 $\beta$ in combination with NE, produced strongly reduced sGAG amounts (Figure 6). Immunohistochemical staining of COMP did not show differences between untreated controls, NE-treated groups, and IL-1 $\beta$ - or IL-1 $\beta$ plus NE-treated chondrocytes (Figure 6). Collagen X deposition in NE-treated groups did not differ from untreated controls, but chondrocytes treated with IL-1 $\beta$ alone or with IL-1 $\beta$ in combination with NE showed a more intense staining for type $X$ collagen (Figure 6). The age or the gender of patients did not influence the NE- and IL-1 $\beta$-mediated changes in ECM deposition during dedifferentiation.

\subsection{Changes in AR Expression during Dedifferentiation}

Expression of detected ARs significantly decreased after seven days of monolayer culture in untreated control groups and in NE-treated groups compared to freshly isolated chondrocytes at day 0 . IL-1 $\beta$ alone or in combination with NE significantly inhibited the expression of ARs (Figure 7, $p$-values are indicated). In contrast, no changes in IL-1 $\beta R$ gene expression were observed (Supplementary Figure S2). Neither NE nor IL-1 $\beta$ alone or in combination with NE influenced IL-1 $\beta$ R expression compared to day 0 chondrocytes and to untreated controls at day 7 significantly (Supplementary Figure S2). 


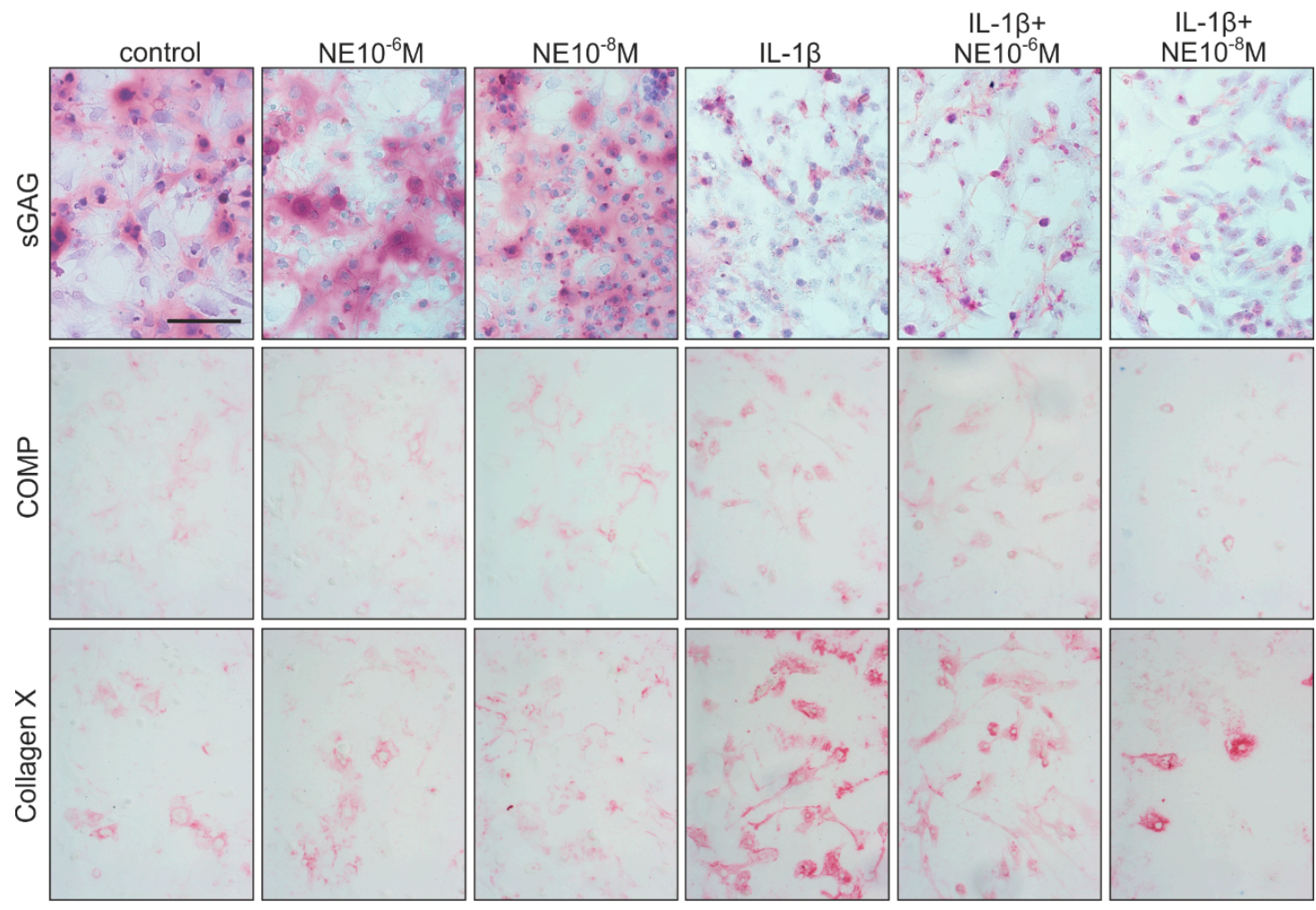

Figure 6. Effects of NE and IL-1 $\beta$ on ECM deposition. DMMB staining of sGAGs and immunohistochemical detection of COMP and type $X$ collagen in OA chondrocyte cultures after seven days under NE or/and IL-1 $\beta$ influence and physioxic conditions (representative images of cells isolated form one OA patient). Scale bar represents $100 \mu \mathrm{m}$.
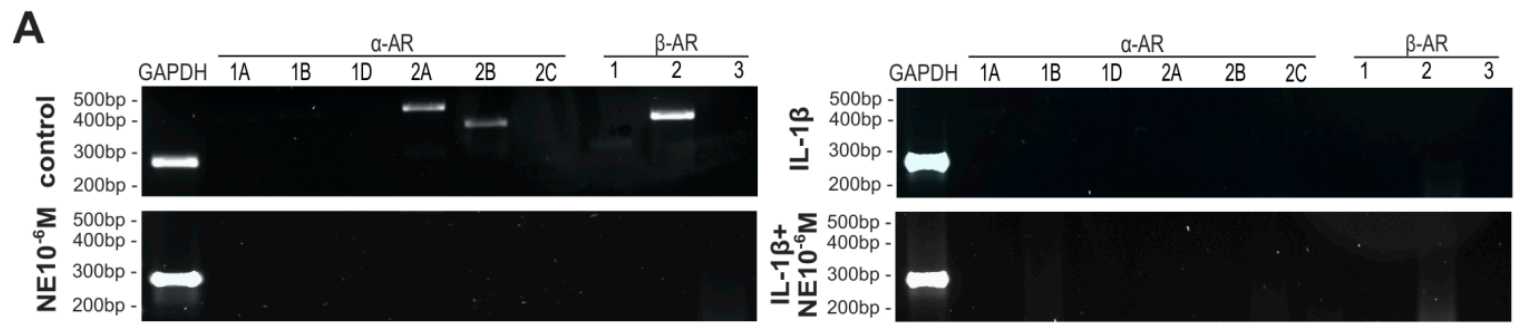

B

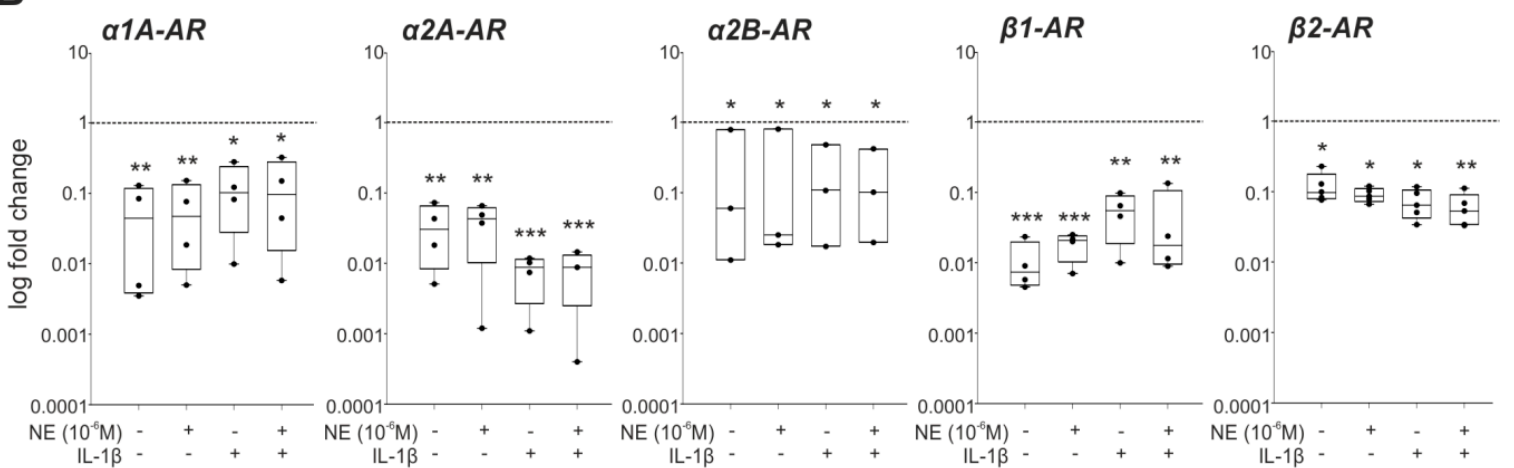

Figure 7. Adrenergic receptor profile of OA chondrocytes after seven days in monolayer culture. (A) Gene expression of different adrenoceptor subtypes in untreated or NE- and/or IL-1 $\beta$-treated primary chondrocytes at day 7 (representative images of cells isolated form one OA patient). (B) Quantitative PCR analysis of expression levels of adrenoceptor subtypes at day 0 and after seven days without treatment as well as under NE or/and IL-1 $\beta$ influence and physioxic conditions. Significant $p$-values against day 0 are presented as: ${ }^{*}(p \leq 0.05),{ }^{* *}(p \leq 0.01),{ }^{* * *}(p \leq 0.001)$. 


\section{Discussion}

The pathogenesis of $\mathrm{OA}$, a chronic degenerative and secondary inflammatory whole joint disease $[25,26]$, is influenced by numerous factors, such as biomechanics, age, gender, genetics, and diet [27]. The first pathologic changes arise in the articular cartilage tissue [26]. At the cellular level, processes like chondrocyte clustering or apoptosis, hypertrophy, and dedifferentiation are involved in OA progression [12,26]. The major factor inducing chondrocyte dedifferentiation is the pro-inflammatory cytokine IL-1 $\beta$ [12]. During the past decade, the role of the sympathetic nervous system, in particular the role of NE, in manifestation and progression of OA has attracted increasing attention. However, studies describing mostly catabolic effects of NE in chondrocytes were performed under hyperoxic conditions and did not focus on the process of chondrocyte dedifferentiation [19]. Moreover, the effect of OA-specific low-grade inflammation alone or in combination with NE has never been investigated in this context. Therefore, we analyzed, for the first time, the influence of NE on monolayer chondrocytes in the presence and absence of IL- $1 \beta$ under physioxic condition, with special regard to the dedifferentiation process.

As a first step, human articular chondrocytes obtained from OA patients were cultivated in monolayer culture under physioxia $\left(2 \% \mathrm{O}_{2}\right)$ for seven days in order to initiate the dedifferentiation process in vitro [10]. Most existing studies dealing with chondrocyte dedifferentiation chose much longer culture periods or even repetitive passaging [28,29]. The gene expression profile of chondrocytes losing their phenotype during long-term dedifferentiation is well characterized under hyperoxic conditions $\left(20 \% \mathrm{O}_{2}\right)$ : Expression of hyaline cartilage matrix-specific genes such as SOX9, COL2A1, ACAN, COMP, and COL10A1 massively decreased [30-32], whereas COL1A1, characteristic for fibrocartilage, greatly increased $[9,10]$. In addition, gene expression of the matrix-degrading enzymes MMP-13, ADAMTS4, and ADAMTS5 is reduced in chondrocytes dedifferentiated under hyperoxia at passage four [10]. Under physioxia, the long-term dedifferentiation process is decelerated, as characterized by a lesser increase in COL1A1 and unchanged or increased SOX9, COL2A1, and ACAN genes $[23,33]$. In the present study, chondrocytes already showed the characteristic morphological shift towards a fibroblast-like shape after seven days under physioxia [10,34,35]. In contrast to morphological changes, the expression of hyaline cartilage matrix-specific genes was not as strongly altered in monolayer culture after seven days under physioxia: COL1A1gene expression increased, COL10A1, MMP-13, and ADAMTS4 decreased, COL2A1 increased, and SOX9, COMP, ACAN, and ADAMTS5 gene expression remained unchanged, suggesting that our physioxic chondrocyte culture was in an intermediate stage after seven days in monolayer [36]. However, the dedifferentiation process was initiated and we believe that seven days in physioxic chondrocyte monolayer culture is an adequate condition to monitor the effects of specific treatments potentially affecting or modulating the dedifferentiation process. We therefore treated freshly isolated chondrocytes for the first time with IL- $1 \beta$ and NE and performed our analysis after seven days of culture so as to not miss regulatory events within this early phase of the dedifferentiation process.

It has been reported earlier that NE and IL-1 $\beta$ are present in the synovial fluid of OA patients in physiological or pathophysiological concentrations, respectively $[13,18]$. However, the expression of the corresponding specific ARs, as well as the IL-1 $\beta R$ on the target cell, is a prerequisite for their action. In freshly isolated chondrocytes, we could confirm the expression of different AR subtypes as well as of the IL- $1 \beta R$. The ARs $\alpha 1 A-, \alpha 2 A-, \beta 2-A R$, and the IL- $1 \beta R$, were strongly expressed, while $\alpha 2 B-$ and $\alpha 2 \mathrm{C}-\mathrm{AR}$ expression was weak. $\alpha 1 \mathrm{~B}-, \alpha 1 \mathrm{D}-, \alpha 2 \mathrm{~B}-$, and $\beta 3-\mathrm{AR}$ could not be detected at mRNA level. The only comparable study analyzing AR expression in OA chondrocytes was performed by Lorenz et. al. [19] and they also found strongly expressed $\alpha 2 A-\beta 2-A R$, but no $\alpha 1 \mathrm{~A}-\mathrm{AR}$. One reason for the lack of $\alpha 1 \mathrm{~A}-\mathrm{AR}$ expression in Lorenz's study could be that hyperoxic culture conditions might affect AR expression [37]. Furthermore, earlier studies described that OA articular chondrocytes express IL-1 $\beta R$, which has been now confirmed by our study [12]. In order to consider possible autocrine effects, gene expression of TH was analyzed. In contrast to Lorenz et al. [19], TH was not detectable in our freshly isolated OA chondrocytes, therefore, autocrine effects can be excluded. 
Since NE usually exhibits opposite dual effects via different $\alpha$ - and $\beta$ ARs, two relevant NE concentrations were tested in our monolayer model in presence or absence of IL-1 $\beta$. Interestingly, $\mathrm{NE}$ alone, in low or in high concentration, affected neither chondrocyte morphology, ECM-specific gene expression, nor ECM deposition, although other studies showed clear inhibition of ECM synthesis [38] as well as proliferative or apoptotic effects [19]. One possible explanation is that these authors focused on three-dimensional redifferentiation processes after dedifferentiation and not exclusively on chondrocyte dedifferentiation in monolayer culture.

Though the strong dedifferentiation-inducing effects of IL-1 $\beta$ are well-known, most previous studies used extremely high IL- $1 \beta$ concentrations (at least several $\mathrm{ng} / \mathrm{mL}$ ) which are more than $10-100$-fold higher than actually measured in OA synovial fluid samples $[13,14]$. In the present study, we used OA-relevant IL-1 $\beta$ concentrations and observed an accelerated morphological shift with clearly visible and increased numbers of stress fibers after IL-1 $\beta$ treatment. This observation was described earlier in dedifferentiating chondrocytes [10], however, such an effect was not previously described for low IL-1 $\beta$ concentrations.

The gene expression profile of dedifferentiated chondrocytes has been studied previously by others, but only over much longer culture periods [5,32]. Gene expression levels of analyzed genes in the present study were only influenced when IL-1 $\beta$ was present in the treatment medium. One reason for unchanged COL1A1, COL10A1, and ADAMTS5 expression might be that OA chondrocytes are already IL-1 $\beta$-primed due to the pro-inflammatory milieu in the synovial fluid of OA patients $[13,14]$ and these three genes are not susceptible any more for IL-1 $\beta$ treatment. On the other hand, it is possible that these genes were very responsive to monolayer culture conditions and the observed gene expression levels had already been achieved at very early time points, and therefore no treatment was able to induce further changes. In the case of SOX9, COL2A1, COMP, and ACAN, the observed decrease in gene expression after IL-1 $\beta$ treatment was in accordance with earlier studies using hyperoxic conditions and with treatments with much higher IL- $1 \beta$ concentrations $[6,10]$. Concomitantly with SOX9, COL2A1, COMP, and ACAN inhibition, low-dose IL-1 $\beta$ treatment resulted in upregulation of MMP13 gene and in unchanged COL10A1 and ADAMTS gene expression levels, suggesting that IL-1 $\beta$ not only downregulates several hyaline cartilage-specific ECM genes, but also perpetuates ECM degradation by preserving high expression levels of distinct matrix-degrading enzymes [12].

In order to confirm our findings at the protein level, selected ECM molecules were stained histologically and immunohistologically. As expected, IL-1 $\beta$ strongly inhibited sGAG deposition in line with the above-mentioned ACAN gene expression data and as known for long-time dedifferentiation cultures $[6,10]$. In contrast to our PCR results, COMP staining intensity was not affected by IL-1 $\beta$ treatment, and type $X$ collagen staining was more intense in IL-1 $\beta$-treated groups. One might argue that the decrease in COMP gene expression was initiated shortly before chondrocyte harvest at day 7 and the changes were not yet translated to the protein level, and that COMP protein could equally accumulate extracellularly during seven days physioxic culture (in contrast to hyperoxic conditions) [9]. The opposite might be the reason why type $X$ collagen staining was stronger in IL- $1 \beta$-treated groups. IL-1 $\beta$ might affect COL10A1 immediately after chondrocyte isolation followed by quick but intense type $\mathrm{X}$ collagen protein synthesis, but after one or two days COL10A1 expression decreases due to monolayer culture conditions, which seem to have a strong effect on COL10A1 and could not be modulated by IL-1 $\beta[10,34]$. It is well known that extracellular matrix proteins are characterized by an extended half-life and slow turnover at the protein level $[39,40]$. On the one hand, this fact can explain why expression data at the RNA and protein level do not always match. On the other hand, this underlines the importance of analyzing expression at both levels to understand the full picture. This might also explain why no differences were found at the gene expression level of COL10A1. NE did not exhibit any effect or modulate the effects of IL-1 $\beta$ in our monolayer chondrocyte culture, either at the gene nor at the protein expression level, although the ERK1/2 signaling pathway was activated shortly after NE treatment in freshly isolated chondrocytes as described earlier [38,41], and although Lorenz et al. observed the NE-mediated reversion of IL-1 $\beta$ effects on MMP-13 or GAGs in three-dimensional 
culture [19]. One reason that could explain this surprising phenomenon might be that the expression profile of ARs in chondrocytes massively changes during seven days, and due to NE and IL-1 $\beta$ treatment. In fact, in NE-treated chondrocytes expression of all detected ARs decreased markedly. Downregulation of ARs by NE was already shown in aorta muscle cells, hamster ovary cell lines, and in HT29 cell line (human colon cancer cell line) [42-44], but the inhibitory effect of NE on AR gene expression in human articular chondrocytes was shown for the first time in the present study. Similar dramatic inhibition of AR expression was observed in IL-1 $\beta$-treated groups, where all ARs disappeared at mRNA level. Bucher et al. observed that pro-inflammatory cytokines downregulate $\alpha 1$-ARs in all organs of rats during endotoxemia and Koto et al. found deceased $\beta$-AR expression in rat tracheal and bronchial smooth muscle cells after IL-1 $\beta$ treatment $[45,46]$. Thus, it is highly likely that, besides $\mathrm{NE}, \mathrm{IL}-1 \beta$ is also responsible for AR downregulation in our OA chondrocyte culture. In contrast to earlier studies demonstrating that IL-1 $\beta(1 \mathrm{ng} / \mathrm{mL})$ strongly reduced IL-1 $\beta R$ expression level in human articular chondrocytes [47], IL-1 $\beta$ R expression remained unchanged in our OA chondrocyte culture. Neither NE nor IL-1 $\beta$ alone or combined influence IL-1 $\beta R$ expression, which leads to long-term IL-1 $\beta$ influence without any limitation and might explain also the dominance of IL1-dependent/induced effects. Naldini et al. observed enhanced expression and release of IL-1 $\beta R$ in human peripheral blood mononuclear cells cultured under $2 \% \mathrm{O}_{2}$ concentration for $16-40 \mathrm{~h}$ [48]. Thus, physioxia seems to act as an antagonist of IL-1 $\beta$ and might stabilize IL-1 $\beta$ R expression in our OA chondrocyte culture.

Aging is one of the major risk factors for OA development [49]. With increasing age, the OA-specific loss of articular chondrocyte phenotype is accelerated [50,51]. The sex steroid estrogen has also been shown to influence chondrocyte homeostasis by inducing the expression of specific chondrogenic markers such as type II collagen, and inhibiting catabolic cytokine and MMP expression [52]. However, none of our tested parameters were regulated to be age- or gender-dependent, either with untreated nor with NE- or IL-1 $\beta$-treated chondrocytes. The reason for this might be the low variance of age of the analyzed patients and the fact that most of the female patients were already in the postmenopausal stage of life.

In conclusion, this study demonstrated that low-dose IL-1 $\beta$ is a strong inducer of chondrocyte dedifferentiation even in short-term culture and under physioxic conditions. In contrast and unexpectedly, NE did not exhibit any effect on monolayer chondrocytes, in either low or in high concentrations, even though relevant receptors were present. NE was also not able to modulate the effects of low-dose IL-1 $\beta$. Thus, the very low inflammatory status obviously exerts a dominant effect which massively contributes to the chondrocyte dedifferentiation process during OA pathogenesis and should therefore be targeted early and primarily in OA therapy.

\section{Materials and Methods}

\subsection{Human Articular Chondrocyte Isolation and Culture}

Human articular cartilage samples were obtained from OA patients undergoing total knee replacement surgery. The samples were anonymized, thus no approval by the Ethics Committee of the Goethe University Frankfurt was necessary. All experiments were performed in accordance with relevant guidelines and regulations. The experimental cohort included 10 patients (patient information is given in Table 1).

Table 1. Characteristics of patients in study.

\begin{tabular}{ll}
\hline Patient Characteristics & Number/Mean Age \pm SEM \\
\hline Total (number/age) & $10 / 65.33 \pm 11.77$ \\
Female (number/age) & $6 / 64.83 \pm 12.06$ \\
Male (number/age) & $4 / 66.33 \pm 11.09$ \\
\hline
\end{tabular}

Macroscopically normal-looking cartilage tissue was removed from the subchondral bone, cut into pieces approximately $1 \times 2 \mathrm{~mm}$ in size, and digested with sterile filtered $0.2 \%(w / v)$ pronase (Roche) 
in Dulbecco's modified Eagle medium (DMEM)/F12 (Gibco, Thermo Fisher Scientific, Darmstadt, Germany) containing $1 \%$ penicillin/streptomycin (P/S, Gibco) for $2 \mathrm{~h}$ on a shaker at $37^{\circ} \mathrm{C}$ and at 60 $\mathrm{rpm}$. Then, cartilage pieces were washed three times with $1 \times$ DPBS and digested with sterile filtered $280 \mathrm{U} / \mathrm{mL}$ collagenase II (Biochrom, Berlin, Germany) in DMEM/F12 overnight on a shaker at $37^{\circ} \mathrm{C}$ and at $60 \mathrm{rpm}$. After the digestion steps, the chondrocytes were passed through a $70 \mathrm{~mm}$ nylon mesh (Falcon, VWR, Darmstadt, Germany) to remove residual cartilage fragments, centrifuged at $300 \times g$ for $5 \mathrm{~min}$, resuspended in DMEM/F12 supplemented with 10\% fetal calf serum (FCS, Sigma-Aldrich, Munich, Germany) and 1\% P/S, and seeded in a density of 20,000 cells $/ \mathrm{cm}^{2}$ into T75 cell culture flasks and cultured in a humidified atmosphere at $37{ }^{\circ} \mathrm{C}$ and in $2 \% \mathrm{O}_{2} / 5 \% \mathrm{CO}_{2}$ overnight to allow attachment of cells.

\subsection{Chondrocyte Stimulation}

After overnight attachment, chondrocytes were treated with different concentrations of NE $\left(10^{-8} \mathrm{M}\right.$ or $10^{-6} \mathrm{M}$ representing $\alpha$-AR- or $\beta$-AR-dominant concentrations, Sigma-Aldrich) and/or IL-1 $\beta$ (0.5 ng/mL, OA-specific IL-1 $\beta$ concentration, Peprotech, Hamburg, Germany) in DMEM/F12 supplemented with $10 \% \mathrm{FCS}, 1 \% \mathrm{P} / \mathrm{S}$, and ascorbic acid (Sigma-Aldrich). Chondrocytes were cultured for seven days with NE and/or IL- $1 \beta$ at $37{ }^{\circ} \mathrm{C}$ and in $2 \% \mathrm{O}_{2} / 5 \% \mathrm{CO}_{2}$. Within seven days, chondrocytes started to dedifferentiate without reaching a fully dedifferentiated status, allowing possible manipulation by the distinct treatments. Untreated chondrocytes served as the control group and day 0 chondrocytes as starting point controls. Cell culture medium with freshly diluted supplements was changed on day four. The same experimental setup was performed in chamber slides for histological investigations. After seven days, chondrocyte morphology was documented microscopically and after detachment, cells were counted and frozen at $-80{ }^{\circ} \mathrm{C}$ for analysis. Chondrocytes in chamber slides were fixed using 4\% PFA (Thermo Fisher Scientific, Darmstadt, Germany) for histological investigations. In addition, supernatants were harvested and immediately used for cell viability assay.

\subsection{NE-Dependent Signal Transduction}

In order to examine whether monolayer chondrocytes respond to NE, the two major AR-dependent signaling pathways - the phosphorylation of PKA and ERK1/2-were investigated. Overnight, attached chondrocytes were treated for 15 min with NE $\left(10^{-8}\right.$ or $\left.10^{-6} \mathrm{M}\right)$. Protein isolation was performed using NucleoSpin RNA/Protein kit (Machrey Nagel, Düren, Germany). Samples were loaded onto 10\% SDS-PAGE (sodium dodecyl sulfate polyacrylamide gel electrophoresis) and electrotransferred to a polyvinylidene difluoride (PVDF) membrane. Membranes were blocked with $5 \%$ bovine serum albumin for $1 \mathrm{~h}$ at room temperature before incubation with primary antibodies for total ERK (\#9107; Cell Signaling Technology, Frankfurt/Main, Germany), phosphorylated ERK (\#4370; Cell Signaling Technology), total PKA (\#32514; Abcam, Cambridge, United Kingdom), phosphorylated PKA (\#32390; Abcam), and GAPDH (\#MA5-15738; Thermo Fisher Scientific) at $4{ }^{\circ} \mathrm{C}$ overnight. The membranes were washed with TBST and incubated with HRP-conjugated secondary antibody (DAKO, Hamburg.Germany) for $1 \mathrm{~h}$ at room temperature. The target protein expression was detected using the chemiluminescence (ECL, Scientific, Darmstadt, Germany) reagents, with GAPDH as the endogenous control.

\subsection{Morphological Analyzes}

Chondrocyte cellular morphology, which is directly linked to cell metabolism and ECM synthesis [24] was examined by phase-contrast microscopy as well as staining of the actin cytoskeleton at day 7 of dedifferentiation. For actin staining, fluorescent-labeled phalloidin was used according to manufacturer's instructions (FAK100 Actin Cytoskeleton/Focal Adhesion Staining Kit, Merck, Darmstadt, Germany) followed by documentation at a fluorescence microscope (Nikon, Minato, Japan). 


\subsection{Determination of Cell Viability}

To demonstrate that treatment with NE and IL-1 $\beta$ has no cytotoxic effects, LDH assay (Takara) was performed according to manufacturer's instructions using cell culture supernatants from day 7, cell culture medium without cells, and the dead-control ( $300 \mu \mathrm{L}$ Triton-X per T75 for $15 \mathrm{~min}$ ). Supernatants were analyzed in a 96-well plate as duplicates in a plate reader.

\subsection{RNA Isolation and PCR}

RNA isolation from monolayer chondrocyte pellets was performed using NucleoSpin RNA/Protein kit (Machrey Nagel, Düren, Germany) according to the manufacturer's instructions. Synthesis of cDNA was performed using qScript cDNA Supermix (Quanta Biosciences, VWR, Darmstadt, Germany). For gene expression analysis of different AR subtypes and the IL- $1 \beta$ receptor (IL-1 $\beta R$ ) on chondrocytes at day 0 and day 7, reverse transcription PCR was used (Taq PCR Master Mix kit, Qiagen, Hilden, Germany). PCR products were run on a $1.8 \%(\mathrm{wt} / \mathrm{vol})$ agarose gel, stained with GelRed Nucleic Acid Gel Stain (Biotium, Fremont, CA, USA). In addition, TH gene expression was quantified in order to consider possible autocrine effects. GAPDH served as housekeeping gene. In addition, gene expression changes of ARs and ECM-related genes (SOX9; COL1A1; COL2A1; COL10A1; COMP, ACAN; MMP13; ADAMTS-4; ADAMTS-5) after seven days of monolayer culture were analyzed using Quanta PerfeCta SYBR Green FastMix (Quanta Biosciences, VWR, Darmstadt, Germany) in qTOWER3 Thermocycler (Analytik Jena, Jena, Germany). Relative gene expression was determined by the $\Delta \Delta \mathrm{Ct}$ method using qPCR3.2 software (Analytik Jena) [52]. Human RPII served as housekeeping gene [53,54]. All primers were synthesized by Thermo Fisher Scientific (Table 2).

Table 2. The primers used for PCR.

\begin{tabular}{llll}
\hline Gene Name & NCBI Reference & Forward $\mathbf{( 5}^{\prime} \mathbf{- 3}^{\prime} \mathbf{)}$ & Reverse $^{\left(\mathbf{5}^{\prime}-\mathbf{3}^{\prime} \mathbf{)}\right.}$ \\
\hline GAPDH & NM_001289745.2 & CTCCTGTTCGACAGTCAGCC & TTCCCGTTCTCAGCCTTGAC \\
TH & NM_000360.3 & CAGGCAGAGGCCATCATGT & GTGGTCCAAGTCCAGGTCAG \\
ADRA1A & NM_000680.3 & CCATGCTCCAGCCAAGAGTT & TCCTGTCCTAGACTTCCTCCC \\
ADRA1B & NM_000679.3 & GTCCACCGTCATCTCCATCG & GAACAAGGAGCCAAGCGGTAG \\
ADRA1D & NM_000678.3 & TGACTTTCCGCGATCTCCTG & TTACCTGCCACGGCCATAAG \\
ADRA2A & NM_000681.3 & TGGTCATCGGAGTGTTCGTG & GCCCACTAGGAAGATGGCTC \\
ADRA2B & NM_000682.6 & GACATTTCACCGGCAACACC & GGGACTGAGAACCAGGAAGC \\
ADRA2C & NM_000683.3 & CGATGTGCTGTTTTCACCT & GGATGTACCAGGTCTCGTCG \\
ADRB1 & NM_000684.2 & TAGCAGGTGAACTCGAAGCC & ATCTTCCACTCCGGTCCTCT \\
ADRB2 & NM_000024.5 & CAGAGCCTGCTGACCAAGAA & GCCTAACGTCTTGAGGGCTT \\
ADRB3 & NM_000025.3 & GCCAATTCTGCCTTCAACCC & GCCAGAGGTTTCCACAGGT \\
IL1R1 & NM_000877.4 & AGGGATGACTACGTTGGGGA & CTCCAGCTCAAGCAGGACAA \\
POLR2A & NM_000937.5 & GACACAGGACCACTCATGAAGT & GTGCGGCTGCTTCCATAAG \\
COL1A1 & NM_000088.3 & ACGTCCTGGTGAAGTTGGTC & ACCAGGGAAGCCTCTCTCTC \\
COL2A1 & NM_001844.4 & TTCAGCTATGGAGATGACAATC & AGAGTCCTAGAGTGACTGAG \\
COL10A1 & XM_011535433.3 & CCCTCTTGTTAGTGCCAACC & AGATTCCAGTCCTTGGGTCA \\
COMP & NM_000095.2 & AGGGAGATCGTGCAGACAA & AGCTGGAGCTGTCCTGGTAG \\
SOX9 & NM_000346.4 & ACACACAGCTCACTCGACCTTG & AGGGAATTCTGGTTGCTCCTCT \\
ACAN & NM_001135.3 & TCCCCTGCTATTTCATCGAC & CCAGCAGCACTACCTCCTTC \\
ADAMTS 4 & NM_001320336.1 & AGGGAAGGGGACAAGGACTA & TATCACCACCACCCTGGATT \\
ADAMTS 5 & NM_007038.4 & TACTTGGCCTCTCCCATGAC & TTTGGACCAGGGCTTAGATG \\
MMP13 & NM_002427.4 & GACTGGTAATGGCATCAAGGGA & CACCGGCAAAAGCCACTTTA \\
\hline
\end{tabular}

\subsection{Cytological Staining}

Chondrocytes incubated in chamber slides were stained for ECM components to analyze the effects of NE and/or IL-1 $\beta$ treatment. The metachromatic dye DMMB (0.1\% 1,9-dimethyl-methylene blue, Sigma-Aldrich) in dd. $\mathrm{H}_{2} \mathrm{O}$ was used to detect newly synthesized sGAG. COMP and type $\mathrm{X}$ collagen were stained using polyclonal rabbit primary antibodies (COMP: rabbit anti-COMP 4-1 (Immundiagonstik AG, Bensheim, Germany) [55], 1:100; type X collagen: ab58632, Abcam, Cambridge, United Kingdom, 1:200) and ImmPRESS ${ }^{\mathrm{TM}}$ peroxidase polymer goat anti-rabbit IgG biotin secondary antibody (Linaris, Dossenheim, Germany). Staining was visualized using Vectastain ABC-AP detection Kit (Linaris). 


\subsection{Statistical Analysis}

All experiments were carried out with cells of 4-10 patients. Data were presented as box plots with medians. For statistical evaluation of different groups to the day 0 control group, Wilcoxon signed-rank test (to hypothetical value 1) was used. Comparisons between treatment groups were carried out using one-way ANOVA/Student-Newman-Keuls post hoc test or the non-parametric Mann-Whitney $U$ test and Bonferroni post hoc test. $p$ values less than 0.05 were considered significant. All statistical analyzes were performed using SigmaPlot 14.0 software.

Supplementary Materials: Supplementary materials can be found at http:/ /www.mdpi.com/1422-0067/20/5/ $1212 / s 1$.

Author Contributions: S.S., A.M., F.Z., and Z.J.-L. conceived and designed the experiments; S.S., N.M., and K.E.B. performed the experiments; S.S., F.Z., and Z.J.-L. analyzed the data; A.M. contributed materials; S.S., F.Z., and Z.J.-L. prepared the manuscript.

Funding: This study was supported by grant of the Deutsche Forschungsgemeinschaft (to Z.J.-L. and R.H.S., J.E. 642/4-1 within Research Unit FOR2407 ExCarBon).

Acknowledgments: The authors thank Inna Schaible for excellent technical assistance.

Conflicts of Interest: The authors declare no conflict of interest.

\section{Abbreviations}

$\begin{array}{ll}\text { AR } & \text { Adrenergic receptor } \\ \text { ACAN } & \text { Aggrecan } \\ \text { ADAMTS4 } & \text { ADAM metallopeptidase with thrombospondin type 1 motif } 4 \\ \text { ADAMTS5 } & \text { ADAM metallopeptidase with thrombospondin type 1 motif } 5 \\ \text { cDNA } & \text { Complementary desoxyribonucleic acid } \\ \text { COL1A1 } & \text { Collagen type I alpha 1 chain } \\ \text { COL2A1 } & \text { Collagen type II alpha 1 chain } \\ \text { COL10A1 } & \text { Collagen type X alpha 1 chain } \\ \text { COMP } & \text { Cartilage oligomeric matrix protein } \\ \text { DA } & \text { Dopamine } \\ \text { DMEM } & \text { Dulbecco's modified Eagle's medium } \\ \text { DMMB } & \text { 1,9-Dimethyl-methylene blue } \\ \text { DPBS } & \text { Dulbeccos phosphate-buffered saline } \\ \text { E } & \text { Epinephrine } \\ \text { ECM } & \text { Extracellular matrix } \\ \text { ERK } & \text { Extracellular signal-regulated kinases } \\ \text { FCS } & \text { Fetal calf serum } \\ \text { GAG } & \text { Glycosaminoglycan } \\ \text { GAPDH } & \text { Glyceraldehyde-3-phosphate dehydrogenase } \\ \text { HRP } & \text { Horseradish peroxidase } \\ \text { IL-1 } \beta & \text { Interleukin-1 beta } \\ \text { IL1 } \beta-R ~ & \text { Interleukin-1 receptor type 1 } \\ \text { L-DOPA } & \text { L-3,4-dihydroxyphenylalanin } \\ \text { LDH } & \text { Lactate dehydrogenase } \\ \text { MMP13 } & \text { Matrix metallopeptidase 13 } \\ \text { mRNA } & \text { Messenger ribonucleic acid } \\ \text { NE } & \text { Norepinephrine } \\ \text { OA } & \text { Osteoarthritis } \\ \text { PCR } & \text { Polymerase chain reaction } \\ \text { PFA } & \text { Paraformaldehyde } \\ \text { PKA } & \text { Proteinkinase A } \\ \text { PVDF } & \text { Polyvinylidene difluoride } \\ \text { RPII } & \text { RNA polymerase II subunit A } \\ \text { RT-PCR } & \text { Reverse-transcriptase PCR } \\ \text { sGAG } & \text { Sulphated glycosaminoglycans } \\ & \end{array}$


SDS-PAGE Sodium dodecyl sulfate polyacrylamide gel electrophoresis

SOX9 SRY-box 9

TBST Tris buffered saline with Tween20

TH Tyrosine hydroxylase

\section{References}

1. Lozano, R.; Naghavi, M.; Foreman, K.; Lim, S.; Shibuya, K.; Aboyans, V.; Abraham, J.; Adair, T.; Aggarwal, R.; Ahn, S.Y.; et al. Global and regional mortality from 235 causes of death for 20 age groups in 1990 and 2010: A systematic analysis for the global burden of disease study 2010. Lancet 2012, 380, 2095-2128. [CrossRef]

2. Allen, K.D.; Golightly, Y.M. State of the evidence. Curr. Opin. Rheumatol. 2015, 27, 276-283. [CrossRef] [PubMed]

3. Haq, I.; Murphy, E.; Dacre, J. Osteoarthritis. Postgrad. Med. J. 2003, 79, 377-383. [CrossRef] [PubMed]

4. Studer, D.; Millan, C.; Öztürk, E.; Maniura-Weber, K.; Zenobi-Wong, M. Molecular and biophysical mechanisms regulating hypertrophic differentiation in chondrocytes and mesenchymal stem cells. Eur. Cell Mater. 2012, 24, 118-135, discussion 135. [CrossRef] [PubMed]

5. Darling, E.M.; Athanasiou, K.A. Rapid phenotypic changes in passaged articular chondrocyte subpopulations. J. Orthop. Res. 2005, 23, 425-432. [CrossRef] [PubMed]

6. Zhang, Y.; Chai, G.; Liu, W.; Zhou, G.D.; Cui, L.; Cao, Y.L. Microarray analysis of dedifferentiation related gene expression of human chondrocytes cultured in vitro. Zhonghua Zheng Xing Wai Ke Za Zhi 2007, 23, 331-334. [PubMed]

7. Elima, K.; Vuorio, E. Expression of mrnas for collagens and other matrix components in dedifferentiating and redifferentiating human chondrocytes in culture. FEBS Lett. 1989, 258, 195-198. [CrossRef]

8. Zaucke, F.; Dinser, R.; Maurer, P.; Paulsson, M. Cartilage oligomeric matrix protein (comp) and collagen ix are sensitive markers for the differentiation state of articular primary chondrocytes. Biochem. J. 2001, 358, 17-24. [CrossRef] [PubMed]

9. Rosenzweig, D.H.; Ou, S.J.; Quinn, T.M. P38 mitogen-activated protein kinase promotes dedifferentiation of primary articular chondrocytes in monolayer culture. J. Cell. Mol. Med. 2013, 17, 508-517. [CrossRef] [PubMed]

10. Schulze-Tanzil, G. Activation and dedifferentiation of chondrocytes: Implications in cartilage injury and repair. Ann. Anat. 2009, 191, 325-338. [CrossRef] [PubMed]

11. Daheshia, M.; Yao, J.Q. The interleukin 1beta pathway in the pathogenesis of osteoarthritis. J. Rheumatol. 2008, 35, 2306-2312. [CrossRef] [PubMed]

12. Jenei-Lanzl, Z.; Meurer, A.; Zaucke, F. Interleukin-1ß signaling in osteoarthritis-Chondrocytes in focus. Cell Signal. 2018, 53, 212-223. [CrossRef] [PubMed]

13. Panina, S.B.; Krolevets, I.V.; Milyutina, N.P.; Sagakyants, A.B.; Kornienko, I.V.; Ananyan, A.A.; Zabrodin, M.A.; Plotnikov, A.A.; Vnukov, V.V. Circulating levels of proinflammatory mediators as potential biomarkers of post-traumatic knee osteoarthritis development. J. Orthop. Traumatol. 2017, 18, 349-357. [CrossRef] [PubMed]

14. McNulty, A.L.; Rothfusz, N.E.; Leddy, H.A.; Guilak, F. Synovial fluid concentrations and relative potency of interleukin-1 alpha and beta in cartilage and meniscus degradation. J. Orthop. Res. 2013, 31, 1039-1045. [CrossRef] [PubMed]

15. Kim, M.; Yoo, S.J.; Kang, S.W.; Kwon, J.; Choi, I.; Lee, C.H. Tnf $\alpha$ and il-1 $\beta$ in the synovial fluid facilitate mucosal-associated invariant $\mathrm{t}$ (mait) cell migration. Cytokine 2017, 99, 91-98. [CrossRef] [PubMed]

16. Grässel, S.; Muschter, D. Peripheral nerve fibers and their neurotransmitters in osteoarthritis pathology. Int. J. Mol. Sci. 2017, 18, 931. [CrossRef] [PubMed]

17. Mach, D.B.; Rogers, S.D.; Sabino, M.C.; Luger, N.M.; Schwei, M.J.; Pomonis, J.D.; Keyser, C.P.; Clohisy, D.R.; Adams, D.J.; O'Leary, P.; et al. Origins of skeletal pain: Sensory and sympathetic innervation of the mouse femur. Neuroscience 2002, 113, 155-166. [CrossRef]

18. Jenei-Lanzl, Z.; Grässel, S.; Pongratz, G.; Kees, F.; Miosge, N.; Angele, P.; Straub, R.H. Norepinephrine inhibition of mesenchymal stem cell and chondrogenic progenitor cell chondrogenesis and acceleration of chondrogenic hypertrophy. Arthritis Rheumatol. 2014, 66, 2472-2481. [CrossRef] [PubMed]

19. Lorenz, J.; Schäfer, N.; Bauer, R.; Jenei-Lanzl, Z.; Springorum, R.H.; Grässel, S. Norepinephrine modulates osteoarthritic chondrocyte metabolism and inflammatory responses. Osteoarthr. Cartil. 2016, 24, 325-334. [CrossRef] [PubMed] 
20. Molinoff, P.B. Alpha- and beta-adrenergic receptor subtypes properties, distribution and regulation. Drugs 1984, 28 (Suppl. 2), 1-15. [CrossRef]

21. Grässel, S.; Straub, R.H.; Jenei-Lanzl, Z. The sensory and sympathetic nervous system in cartilage physiology and pathophysiology. In Cartilage; Grässel, S., Aszódi, A., Eds.; Springer Nature: Cham, Switzerland, 2017; Volume 2, pp. 191-227.

22. Brighton, C.T.; Heppenstall, R.B. Oxygen tension in zones of the epiphyseal plate, the metaphysis and diaphysis. An in vitro and in vivo study in rats and rabbits. J. Bone Joint Surg. Am. 1971, 53, 719-728. [CrossRef] [PubMed]

23. Mennan, C.; Garcia, J.; McCarthy, H.; Owen, S.; Perry, J.; Wright, K.; Banerjee, R.; Richardson, J.B.; Roberts, S. Human articular chondrocytes retain their phenotype in sustained hypoxia while normoxia promotes their immunomodulatory potential. Cartilage 2018. [CrossRef] [PubMed]

24. Haudenschild, D.R.; Chen, J.; Steklov, N.; Lotz, M.K.; D’Lima, D.D. Characterization of the chondrocyte actin cytoskeleton in living three-dimensional culture: Response to anabolic and catabolic stimuli. Mol. Cell. Biomech. 2009, 6, 135-144. [PubMed]

25. Goldring, M.B.; Otero, M. Inflammation in osteoarthritis. Curr. Opin. Rheumatol. 2011, 23, 471-478. [CrossRef] [PubMed]

26. Loeser, R.F.; Goldring, S.R.; Scanzello, C.R.; Goldring, M.B. Osteoarthritis: A disease of the joint as an organ. Arthritis Rheumatol. 2012, 64, 1697-1707. [CrossRef] [PubMed]

27. Mobasheri, A.; Batt, M. An update on the pathophysiology of osteoarthritis. Ann. Phys. Rehabil. Med. 2016, 59, 333-339. [CrossRef] [PubMed]

28. Diaz-Romero, J.; Gaillard, J.P.; Grogan, S.P.; Nesic, D.; Trub, T.; Mainil-Varlet, P. Immunophenotypic analysis of human articular chondrocytes: Changes in surface markers associated with cell expansion in monolayer culture. J. Cell Physiol. 2005, 202, 731-742. [CrossRef] [PubMed]

29. Cheng, T.; Maddox, N.C.; Wong, A.W.; Rahnama, R.; Kuo, A.C. Comparison of gene expression patterns in articular cartilage and dedifferentiated articular chondrocytes. J. Orthop. Res. 2012, 30, 234-245. [CrossRef] [PubMed]

30. Benya, P.D.; Padilla, S.R.; Nimni, M.E. Independent regulation of collagen types by chondrocytes during the loss of differentiated function in culture. Cell 1978, 15, 1313-1321. [CrossRef]

31. Stokes, D.G.; Liu, G.; Dharmavaram, R.; Hawkins, D.; Piera-Velazquez, S.; Jimenez, S.A. Regulation of type-ii collagen gene expression during human chondrocyte de-differentiation and recovery of chondrocyte-specific phenotype in culture involves sry-type high-mobility-group box (sox) transcription factors. Biochem. J. 2001, 360, 461-470. [CrossRef] [PubMed]

32. Lin, Z.; Fitzgerald, J.B.; Xu, J.; Willers, C.; Wood, D.; Grodzinsky, A.J.; Zheng, M.H. Gene expression profiles of human chondrocytes during passaged monolayer cultivation. J. Orthop. Res. 2008, 26, 1230-1237. [CrossRef] [PubMed]

33. Duval, E.; Leclercq, S.; Elissalde, J.M.; Demoor, M.; Galéra, P.; Boumédiene, K. Hypoxia-inducible factor 1alpha inhibits the fibroblast-like markers type $\mathrm{i}$ and type iii collagen during hypoxia-induced chondrocyte redifferentiation: Hypoxia not only induces type ii collagen and aggrecan, but it also inhibits type i and type iii collagen in the hypoxia-inducible factor 1alpha-dependent redifferentiation of chondrocytes. Arthritis Rheumatol. 2009, 60, 3038-3048.

34. Duan, L.; Ma, B.; Liang, Y.; Chen, J.; Zhu, W.; Li, M.; Wang, D. Cytokine networking of chondrocyte dedifferentiation in vitro and its implications for cell-based cartilage therapy. Am. J. Transl. Res. 2015, 7, 194-208. [PubMed]

35. Thompson, C.L.; Plant, J.C.; Wann, A.K.; Bishop, C.L.; Novak, P.; Mitchison, H.M.; Beales, P.L.; Chapple, J.P.; Knight, M.M. Chondrocyte expansion is associated with loss of primary cilia and disrupted hedgehog signalling. Eur. Cell Mater. 2017, 34, 128-141. [CrossRef] [PubMed]

36. Zheng, M.H.; King, E.; Kirilak, Y.; Huang, L.; Papadimitriou, J.M.; Wood, D.J.; Xu, J. Molecular characterisation of chondrocytes in autologous chondrocyte implantation. Int. J. Mol. Med. 2004, 13, 623-628. [CrossRef] [PubMed]

37. Eckhart, A.D.; Zhu, Z.; Arendshorst, W.J.; Faber, J.E. Oxygen modulates alpha 1b-adrenergic receptor gene expression by arterial but not venous vascular smooth muscle. Am. J. Physiol. 1996, 271, H1599-H1608. [CrossRef] [PubMed] 
38. Mitchell, J.; Lai, L.P.; Peralta, F.; Xu, Y.; Sugamori, K. B2-adrenergic receptors inhibit the expression of collagen type ii in growth plate chondrocytes by stimulating the ap-1 factor jun-b. Am. J. Physiol. Endocrinol. Metab. 2011, 300, E633-E639. [CrossRef] [PubMed]

39. Aigner, T.; Reichenberger, E.; Bertling, W.; Kirsch, T.; Stoss, H.; von der Mark, K. Type x collagen expression in osteoarthritic and rheumatoid articular cartilage. Virchows Archiv. B Cell Pathol. Incl. Mol. Pathol. 1993, 63, 205-211. [CrossRef]

40. Verzijl, N.; DeGroot, J.; Bank, R.A.; Bayliss, M.T.; Bijlsma, J.W.; Lafeber, F.P.; Maroudas, A.; TeKoppele, J.M. Age-related accumulation of the advanced glycation endproduct pentosidine in human articular cartilage aggrecan: The use of pentosidine levels as a quantitative measure of protein turnover. Matrix Biol. 2001, 20, 409-417. [CrossRef]

41. Jiao, K.; Zeng, G.; Niu, L.N.; Yang, H.X.; Ren, G.T.; Xu, X.Y.; Li, F.F.; Tay, F.R.; Wang, M.Q. Activation of alpha2a-adrenergic signal transduction in chondrocytes promotes degenerative remodelling of temporomandibular joint. Sci. Rep. 2016, 6, 30085. [CrossRef] [PubMed]

42. Heck, D.A.; Bylund, D.B. Mechanism of down-regulation of alpha-2 adrenergic receptor subtypes. J. Pharmacol. Exp. Ther. 1997, 282, 1219-1227. [PubMed]

43. Wikberg, J.E.; Akers, M.; Caron, M.G.; Hagen, P.O. Norepinephrine-induced down regulation of alpha 1 adrenergic receptors in cultured rabbit aorta smooth muscle cells. Life Sci. 1983, 33, 1409-1417. [CrossRef]

44. Hadcock, J.R.; Malbon, C.C. Down-regulation of beta-adrenergic receptors: Agonist-induced reduction in receptor mrna levels. Proc. Natl. Acad. Sci. USA 1988, 85, 5021-5025. [CrossRef] [PubMed]

45. Bucher, M.; Kees, F.; Taeger, K.; Kurtz, A. Cytokines down-regulate alpha1-adrenergic receptor expression during endotoxemia. Crit. Care Med. 2003, 31, 566-571. [CrossRef] [PubMed]

46. Koto, H.; Mak, J.C.; Haddad, E.B.; Xu, W.B.; Salmon, M.; Barnes, P.J.; Chung, K.F. Mechanisms of impaired beta-adrenoceptor-induced airway relaxation by interleukin-1beta in vivo in the rat. J. Clin. Investig. 1996, 98, 1780-1787. [CrossRef] [PubMed]

47. McCollum, R.; Martel-Pelletier, J.; DiBattista, J.; Pelletier, J.P. Regulation of interleukin 1 receptors in human articular chondrocytes. J. Rheumatol. Suppl. 1991, 27, 85-88. [PubMed]

48. Naldini, A.; Pucci, A.; Carraro, F. Hypoxia induces the expression and release of interleukin 1 receptor antagonist in mitogen-activated mononuclear cells. Cytokine 2001, 13, 334-341. [CrossRef] [PubMed]

49. Van der Kraan, P.; Matta, C.; Mobasheri, A. Age-related alterations in signaling pathways in articular chondrocytes: Implications for the pathogenesis and progression of osteoarthritis-A mini-review. Gerontology 2017, 63, 29-35. [CrossRef] [PubMed]

50. Rahmati, M.; Nalesso, G.; Mobasheri, A.; Mozafari, M. Aging and osteoarthritis: Central role of the extracellular matrix. Ageing Res. Rev. 2017, 40, 20-30. [CrossRef] [PubMed]

51. Van Beuningen, H.M.; van der Kraan, P.M.; Arntz, O.J.; van den Berg, W.B. In vivo protection against interleukin-1-induced articular cartilage damage by transforming growth factor-beta 1: Age-related differences. Ann. Rheum. Dis. 1994, 53, 593-600. [CrossRef] [PubMed]

52. Moslemi, S.; Demoor, M.; Boumediene, K.; Galera, P.; Maneix, L. Estrogens Involvement in the Physiopathology of Articular Cartilage, Challenges in Rheumatology. Available online: https:/ / www.intechopen.com/books/challenges-in-rheumatology/estrogens-involvement-in-thephysiopathology-of-articular-cartilage (accessed on 9 March 2018).

53. Livak, K.J.; Schmittgen, T.D. Analysis of relative gene expression data using real-time quantitative pcr and the 2(-delta delta c(t)) method. Methods 2001, 25, 402-408. [CrossRef] [PubMed]

54. Foldager, C.B.; Munir, S.; Ulrik-Vinther, M.; Søballe, K.; Bünger, C.; Lind, M. Validation of suitable house keeping genes for hypoxia-cultured human chondrocytes. BMC Mol. Biol. 2009, 10, 94. [CrossRef] [PubMed]

55. Spitznagel, L.; Nitsche, D.P.; Paulsson, M.; Maurer, P.; Zaucke, F. Characterization of a pseudoachondroplasiaassociated mutation (his587->arg) in the c-terminal, collagen-binding domain of cartilage oligomeric matrix protein (comp). Biochem. J. 2004, 377, 479-487. [CrossRef] [PubMed]

(C) 2019 by the authors. Licensee MDPI, Basel, Switzerland. This article is an open access article distributed under the terms and conditions of the Creative Commons Attribution (CC BY) license (http:/ / creativecommons.org/licenses/by/4.0/). 